\title{
Articles
}

\section{Electrochemical Behaviors of Hydroquinone on a Carbon Paste Electrode with Ionic Liquid as Binder}

\author{
Wei Sun, Qiang Jiang, Maoxia Yang, and Kui Jiao \\ Key Laboratorv of Eco-Chemical Engineering of Ministrv of Education. College of Chemistry and Molecular Engineering, \\ Qingdao Chiversitu of Science and Techologv, Oingdao 266042. P.R. China. ${ }^{*}$ E-mail: sumweigqusteducn \\ Recened December 9. 2007
}

In this paper the electrochemical behaviors of hydroquinone $\left(\mathrm{H}_{2} \mathrm{Q}\right)$ were investigated on a carbon paste electrode using room temperature ionic liquid 1 -butylpyridiniun hexafluorophosphate (BPPF 6 ) as binder ( $\mathbb{L}$ CPE) and further applied to $\mathrm{H}_{2} \mathrm{Q}$ determination. In $\mathrm{pH} 2.5$ phosphate buffer solution (PBS), the electrochemical response of $\mathrm{H}_{2} \mathrm{Q}$ was greatly improved on the $\mathbb{L}-\mathrm{CPE}$ with a pair of well-defined quasi-reversible redox peaks appeared. which was attributed to the electrocataly tic activity of IL-CPE to the $\mathrm{H}_{2} \mathrm{Q}$. The redox peak potentials were located at $0.340 \mathrm{~V}(\mathrm{Epa})$ and $0.240 \mathrm{~V}(\mathrm{Epc})$ ( $v$ s. the saturated calomel electrode. SCE). respectively. The formal potential $\left(\mathrm{E}^{(i)}\right)$ was calculated as $0.290 \mathrm{~V}$ and the peak-to-peak separation $\left(\Delta \mathrm{E}_{j}\right)$ was $0.100 \mathrm{~V}$. The electrochemical parameters of $\mathrm{H}_{2} \mathrm{Q}$ on the IL-CPE were further calculated by cyclic voltanmetry. Under the selected conditions the anodic peak current was linear with $\mathrm{H}_{2} \mathrm{Q}$ concentration over the range from $5.0 \times 10^{-6}$ to $5.0 \times 10^{-3} \mathrm{~mol} \mathrm{~L}^{-1}$ with the detection limit as $2.5 \times 10^{-6} \mathrm{~mol} \mathrm{~L}^{-1}(3 \sigma)$ by cyclic voltammetry. The proposed method was successful applied to determination of $\mathrm{H}_{2} \mathrm{Q}$ content in a synthetic wastewater sample without the interferences of commonly coexisting substances.

Key Words : Hydroquinone. Ionic liquid. Carbon paste electrode. Electrochemistry. Cyclic voltammetry

\section{Introduction}

Chenically modified electrode (CME) had been widely used in the field of electroanalysis due to its advantages such as lower costs. high sensitivity and good selectivity. ${ }^{1-3}$ Different kinds of modifiers had been used to fabricate different types of CME with specific structures and functions. Recently room temperature ionic liquids (RTILs) had been used as a new kind of modifier for the CME. Due to the advantages of wider electrochenical window, higher ionic conductivity and good solubility. RTILs have the great potential applications in the field of electrochemistry and electroanalysis. ${ }^{4-6}$ Maleki et $a t$. fabricated a novel carbon ionic liquid electrode by using a pyridinium-based ionic liquid as binder to replace paraffin. which not only provided a low background response but also showed enhanced high electrochemical performance. ${ }^{7}$ Dong et al. investigated the direct electrochemistry of enzyme in RTILs/carbon nanomaterials composite film modified electrode. ${ }^{8}$ Sun et al. constructed a l-butyl-3-methylimidazolium hexafluorophosphate (BMIMPF $)_{6}$ based carbon ionic liquid electrode and used it as the basal electrode to make a hemoglobin (Hb) modified electrode. The RTILs film modified electrodes were also use for the determination of dopamine (DA), uric acid (UA), chlorpromazine and nitric oxide (NO) efc ${ }^{1(i-13}$ Zhao et al. also prepared a RTILs/carbon nanotube (CNT) composite film modified electrode for the voltammetric determination of DA in the presence of UA and $\mathrm{AA}^{1+}$

Hydroquinone $\left(\mathrm{H}_{2} \mathrm{Q}, 1,4\right.$-dily droxybenzene) is an important substance in chemical industry with its many applications in the fields such as photographic developers. lithography. food antioxidants and the production of polymerization inhibitors for rubber. It is also commonly present in the environmental samples such as coast water. so it is necessary to establish a simple and sensitive method for $\mathrm{H}_{2} \mathrm{Q}$ deternination. Several analytical methods such as chromatographly, ${ }^{15-17}$ electrochemistry ${ }^{18,19}$ and biosensors ${ }^{20.29}$ etc. have been developed for the $\mathrm{H}_{2} \mathrm{Q}$ determination in cosmetic creams and wastewater from photographic process.

In this paper the electrochenical behaviors of $\mathrm{H}_{2} \mathrm{Q}$ were studied on a pyridinium-based ionic liquid modified carbon paste electrode (IL-CPE). In recent reports, ${ }^{7,3, ?, 24} \mathrm{IL}-\mathrm{CPE}$ had been demonstrated as a high-performance electrode with the advantages such as simple preparation procedure. wide potential windows. high rates of electron transfer and good anti-fouling ability. The experimental results indicated that $\mathrm{H}_{2} \mathrm{Q}$ had an improved voltanmetric response on IL-CPE compared with that on the $\mathrm{CPE}$. which was due to the presence of ionic liquid on the electrode surface. The oxidation peak current had a good linear relationship with $\mathrm{H}_{2} \mathrm{Q}$ concentration in the range from $5.0 \times 10^{-6}$ to $5.0 \times 10^{-3} \mathrm{~mol}$ $\mathrm{L}^{-1}$. The proposed method had good ability to distinguish the coexisting catechol and successfully applied to the $\mathrm{H}_{2} \mathrm{Q}$ determination in synthetic wastewater samples. 


\section{Experimental}

Chemicals. Hydroquinone $\left(\mathrm{H}_{2} \mathrm{Q}\right.$, Tianjin Basifu Chemical Linited Company), catechol (CC, Tianjin Kermel Chemical Limited Conpany). $N$-butylpyridinium hexafluorophosphate (BPPF, Hangzhou Kemer Chemical Limited Company). graphite powder (average particle size $30 \mu \mathrm{m}$. Shanghai Colloid Chemical Plant) were used without further treatment. Phosphate buffer solution (PBS) was prepared by mixing suitable amount of $0.1 \mathrm{~mol} \mathrm{~L}^{-1} \mathrm{KH}_{2} \mathrm{PO}_{4} / \mathrm{Na}_{2} \mathrm{HPO}_{4}$ and adjusted to the $\mathrm{pH}$ with $0.1 \mathrm{~mol} \mathrm{~L}^{-1} \mathrm{H}_{3} \mathrm{PO}_{4}$ or $0.1 \mathrm{~mol} \mathrm{~L}-1 \mathrm{NaOH}$. Before experiments the working solution was deoxygenated with pure nitrogen for about $10 \mathrm{~min}$ and the electrochemical cell was kept in the nitrogen atmosphere during all the experiments. All the reagents used were of analytical reagent grade and the solutions were prepared by doubly distilled water.

Apparatus. A LK 98A electrochemical analyzer (Tianjin Lanlike Chenistry and Electron High Teclunology Company, China) was used for all the electrochenical measurements with a traditional three-electrode system. The room temperature ionic liquid modified carbon paste electrode (IL-CPE. $\Phi=4.0 \mathrm{~nm}$ ) was used as the working electrode with a platinum wire as the auxiliary electrode and a saturated calomel electrode (SCE) as the reference electrode. The $\mathrm{pH}$ of PBS was measured by a pHS-25 model pH meter (Shanghai Hongyi Instrumentation Company).

Procedure. The traditional carbon paste electrode (CPE) was prepared by hand-mixing of graphite powder with paraffin at a ratio of $70 / 30(\mathrm{w} / \mathrm{w})$ in an agate mortar. The homogeneous carbon paste was packed into a cavity of glass tube with the diameter of $4.0 \mathrm{~mm}$. The electrical contact was provided with a copper wire connected to the paste in the end of tube. The procedure for the preparation of IL-CPE was carried out according to the reference. ${ }^{35}$ which was made of graphite powder and $\mathrm{BPPF}_{5}$ with a ratio of $3 / 1 \mathrm{kw} /$ w). The sufface of IL-CPE was carefully polished on a piece of weighing paper to get a mirror-like surface just before use

Electrochemical investigation was carried out by cyclic voltammetry in a $0.1 \mathrm{~mol} \mathrm{~L}^{-1} \mathrm{pH} 2.5$ PBS with the potential range from -0.2 to $0.8 \mathrm{~V}$ and the scan rate as $100 \mathrm{mV} \mathrm{s}^{-1}$. All the measurements were carried out at room temperature.

\section{Results and Discussion}

Cyclic voltammogram of $\mathrm{H}_{2} \mathrm{Q}$. Figure 1 showed the cyclic voltammograms of $\mathrm{H}_{2} \mathrm{Q}$ on traditional $\mathrm{CPE}$ (curve a) and IL-CPE (curve b) with the scan rate as $100 \mathrm{mV} \mathrm{s}^{-1}$. On the CPE, a pair of small redox peaks appeared with the anodic peak potential (Epa) as $0.452 \mathrm{~V}$ and the cathodic peak potential (Epc) as $0.120 \mathrm{~V}$ (vs. SCE). The anodic (Ipa) and the cathodic (Ipc) peak current was got as $-41.297 \mu \mathrm{A}$ and $29.253 \mu \mathrm{A}$. respectively. The ratio of $\mathrm{Ipa} / \mathrm{Ipc}$ was calculated as 1.41 and the peak-to-peak separation $\left(\Delta \mathrm{E}_{p}\right)$ was got as $0.332 \mathrm{~V}$. The formal peak potential $\left(E^{i y}\right)$. which is the midpoint of Epa and Epc, was obtained as $0.286 \mathrm{~V}$ ( $v s$. SCE). The results indicated the electrode reaction was a

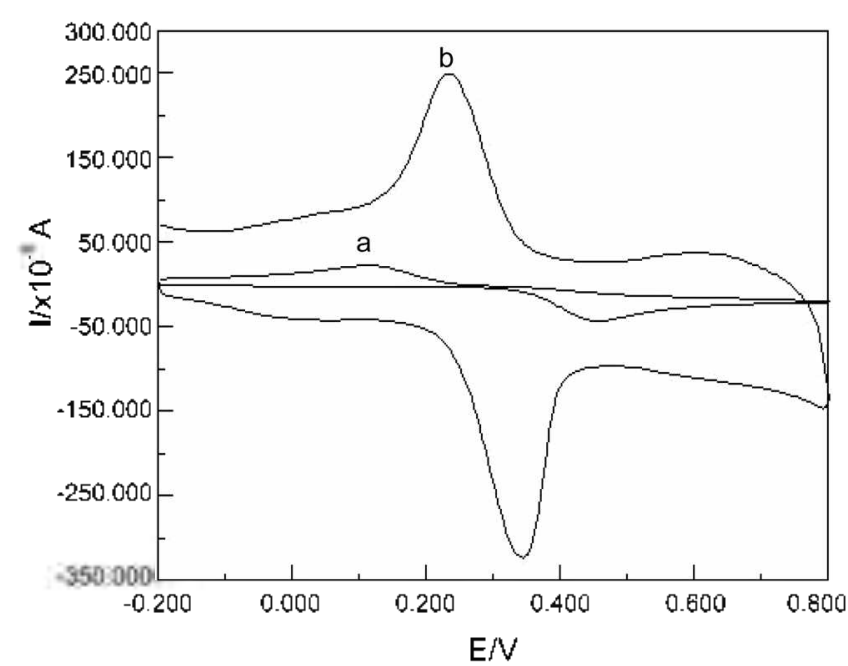

Figure 1. Cyclic voltanmograms of $5.0 \times 10^{-1} \mathrm{~mol} \mathrm{~L}^{-1} \mathrm{H}_{2} \mathrm{Q}$ on CPE (a) and IL-CPE (b) in $\mathrm{pH} 2.5$ PBS. Scan rate: $100 \mathrm{mV} \mathrm{s}^{-1}$.

quasi-reversible process. While on the IL-CPE, the reversibility of $\mathrm{H}_{2} \mathrm{Q}$ was significantly improved with the redox peak current increased greatly. From curve $b$ it can be seen that the anodic peak potential was negatively shifted to $0.340 \mathrm{~V}$ and the cathodic peak potential was positively shifted to $0.240 \mathrm{~V}$. The peak-to-peak separation $\left(\Delta \mathrm{E}_{\mathrm{p}}\right)$ was got as $0.100 \mathrm{~V}$ and the $\mathrm{E}^{\text {it }}$ value as $0.290 \mathrm{~V}$. The peak currents were about 7 folds larger than that on CPE with the ratio of Ipa/Ipc as 1.33. The small $\Delta \mathrm{E}_{\mathrm{p}}$ indicated that the overpotential of $\mathrm{H}_{2} \mathrm{Q}$ at IL-CPE was remarkably lowered and the electrochemical reversibility of $\mathrm{H}_{2} \mathrm{Q}$ on IL-CPE was much improved. At the same time the redox peak current was greatly increased. All the results was the indicative of a electrocatalytic reaction with faster electron transfer rates. ILs have the unique properties such as high conductivity, good solubility and high viscosity. When IL was mixed with graphite powder. it not only acted as a binder to bind the graphite powder together. but also filled into the void spaces

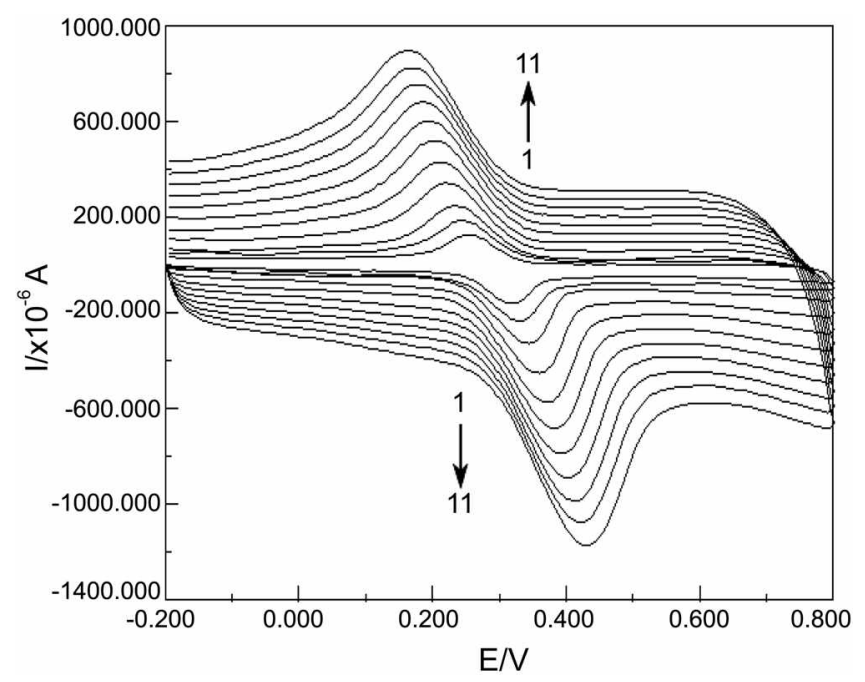

Figure 2. Cyclic voltammograms of $5.0 \times 10^{-1} \mathrm{~mol} \mathrm{~L}^{-1} \mathrm{H}_{2} \mathrm{Q}$ on ILCPE with different scan rates in pH 2.5 PBS. (From 1 to 11 : 30,50 , $\left.100,150,200,250,300,350,400,450,500 \mathrm{mV} \mathrm{s}^{-1}\right)$ 


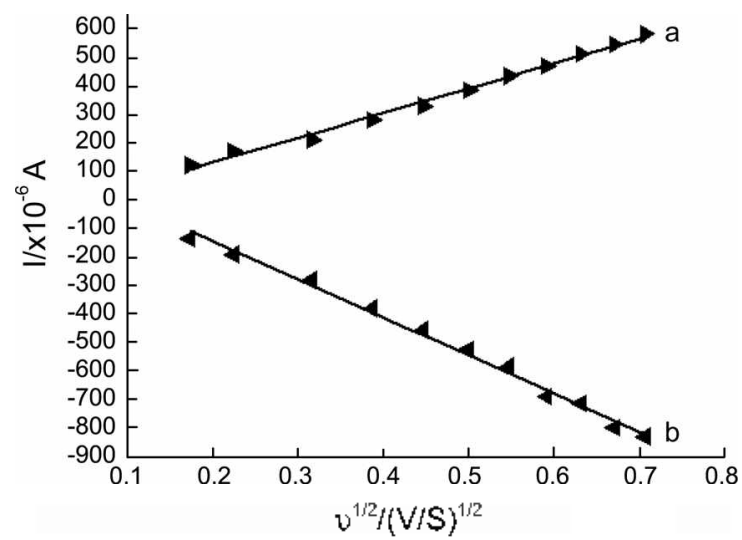

Figure 3. Plots of cathodic (a) and anodic (b) peak culrent with square root of the scan rate $\left(v^{\mathrm{j} 2}\right)$.

between the graphite powders to form an excellent chargetransfer bridge in the bulk of the CPE. A layer of IL was also formed on the surface of IL-CPE. So the significant improvement of the reversibility and sensitivity was achieved on the IL modified carbon paste electrode (IL-CPE). ${ }^{7.24}$

Effect of scan rate. The influence of scan rate on the cyclic voltammetric response of $\mathrm{H}_{-} \mathrm{Q}$ was carefully studied and the results were shown in Figure 2. It can be seen that with the increase of scan rate the redox peak current increased and the peak potential moved gradually.

In the scan rate from 30 to $500 \mathrm{mV} \mathrm{s}^{-1}$ the redox peak current had good linear relationship with the square root of the scan rate $\left(v^{\mathrm{j}}\right)$ and the plot was shown in Figure 3. The results revealed that the electron process was a diffusioncontrolled mechanism.

From Figure 2 it can also be seen that with the increase of scan rate the anodic peak potential was positively moved and the cathodic peak potential was negatively moved with the increase of the peak separation. The results indicated that the electron transfer rate was not very fast and the electrochemical reaction became less reversible. The relationship of redox peak potential with the $\ln v$ was constructed and the results were shown in Figure 4. According to the Laviron's equation ${ }^{26}$ the charge transfer coefficient $(c)$, the electron transfer number (n) and the electron transfer rate constant

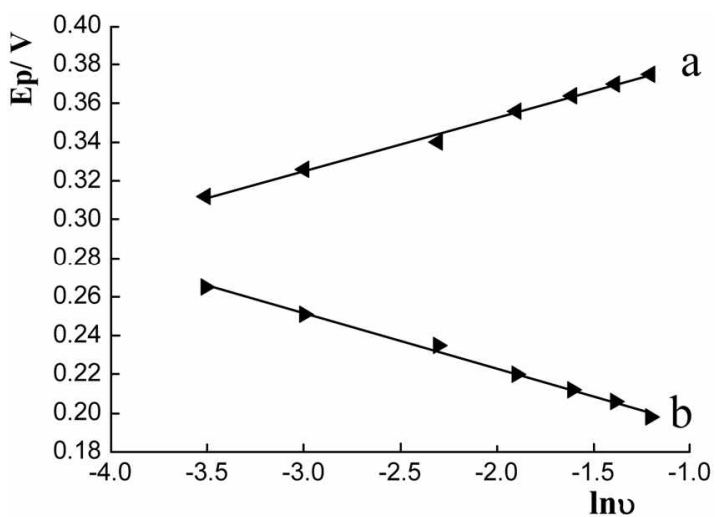

Figure 4. The relationship of the peak potential Epa (a) and Epc (b) against $\ln v$.
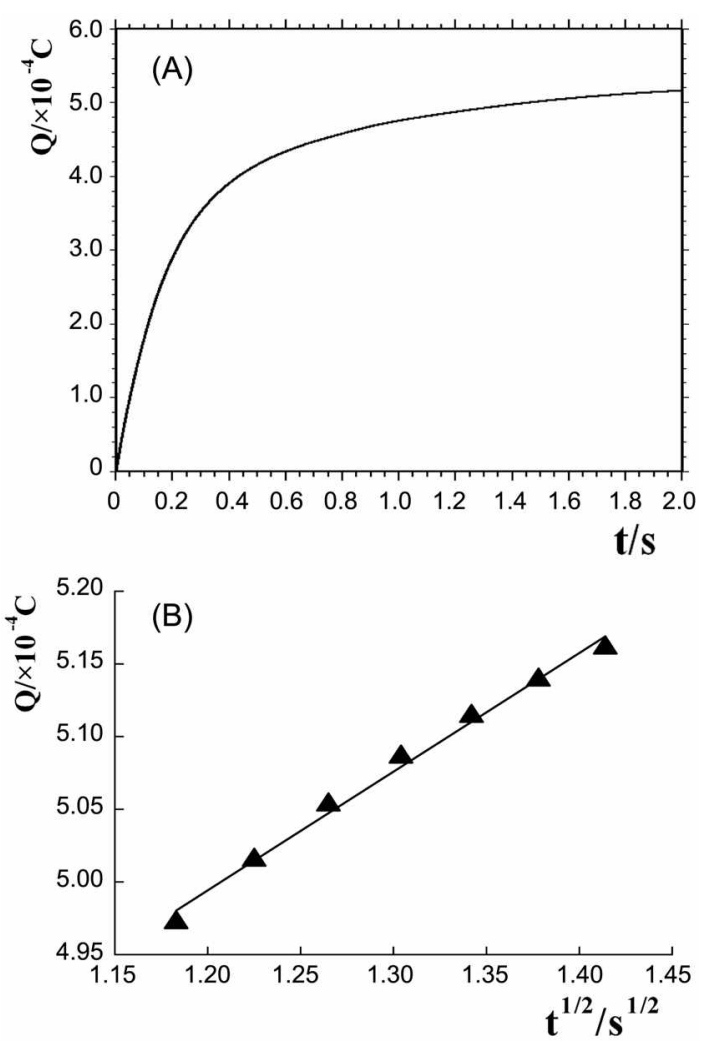

Figure 5. (A) Chronocoulometric curve of $5.0 \times 10^{-1} \mathrm{~mol} \mathrm{~L}^{-1} \mathrm{H}_{2} \mathrm{Q}$, (B) The relationship of $Q$ against $t^{1 ; 2}$

$\left(k_{s}\right)$ were calculated as 0.51 .1 .83 and $1.60 \mathrm{~s}^{-1}$. respectively The value of $k_{s}$ was much larger than a previous reported value on $\mathrm{CPE} .{ }^{27}$ The result indicated that the IL-CPE showed enlanced electron transfer rate constant of $\mathrm{H}_{2} \mathrm{Q}$ than that on $\mathrm{CPE}$. which was mainly due to the presence of high conductive IL as the binder to promote the electron transfer rate.

Effect of buffer pH. The effect of buffer $\mathrm{pH}$ on the electrochemical response of $\mathrm{H}_{2} \mathrm{Q}$ was investigated in the $\mathrm{pH}$ range from 2.0 to 9.0 . The maximum anodic peak current appeared at $\mathrm{pH} 2.5$. which was selected for $\mathrm{H}_{2} \mathrm{Q}$ determination.

In the selected $\mathrm{pH}$ range the formal peak potential $\left(\mathrm{E}^{\mathrm{ir}}\right)$ also shifted negatively with the increase of solution $\mathrm{pH}$. A linear regression equation between $\mathrm{E}^{13}$ and $\mathrm{pH}$ was obtained as $\mathrm{E}^{\mathrm{ir}}(\mathrm{mV})=-57.2 \mathrm{pH}+428.2(\mathrm{n}=9, \gamma=0.997)$. The value of slope was $-57.2 \mathrm{mV} / \mathrm{pH}$. which was close to the theoretical value of $-59.0 \mathrm{mV} / \mathrm{pH}\left(25^{\circ} \mathrm{C}\right)$. According to the equation: $-59.0 \mathrm{x} / \mathrm{n}=-57.2$. the uptaking of electron was accompanied by an equal number of lydrogen ion and $n=x$ $=2$. The results indicated that two-electron transfer accompanied with two-proton transferred.

Chronocoulometric curve. Because the electrode process was controlled by diffusion, the diffusion coefficient (D) of $\mathrm{H}_{2} \mathrm{Q}$ was further determined by chroncoulometric method Figure $5 \mathrm{~A}$ showed the chronocoulometric curve of $5.0 \times$ $10^{-4} \mathrm{~mol} \mathrm{~L}^{-1} \mathrm{H}_{2} \mathrm{Q}$ and the relationship of $\mathrm{Q}$ with $\mathrm{t}^{1: 2}$ was plotted $w$ ith the result shown in Figure 5B. According to the equation given by Anson ${ }^{29}: \mathrm{Q}=2 \mathrm{nFAD} \mathrm{C}^{1 / 4} \mathrm{Ct}^{1: 4} / \pi^{1: 2}+\mathrm{Q}_{\mathrm{d} 1}+$ $\mathrm{Q}_{\mathrm{As}}$. From the slope of the linear relationship between $\mathrm{Q}$ and 


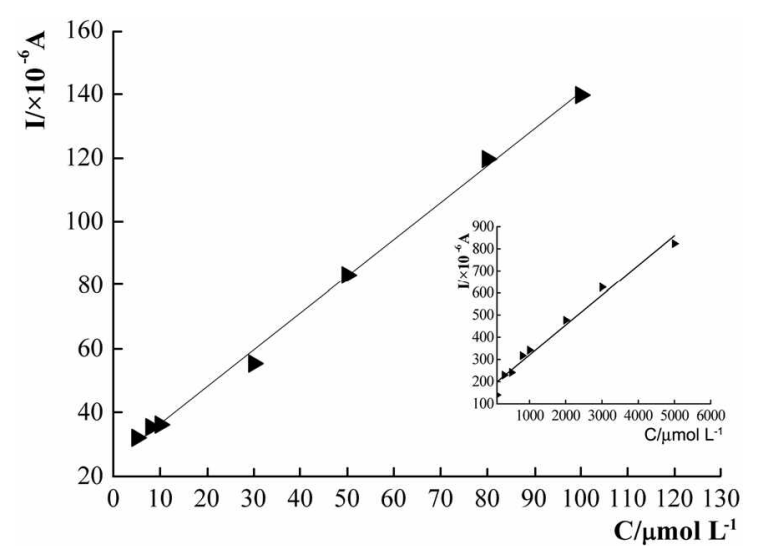

Figure 6. Calibration curve for $\mathrm{H}_{2} \mathrm{Q}$ determination with IL-CPE

$\mathrm{t}^{1: 2}$. the value of $\mathrm{D}$ was calculated as $7.88 \times 10^{-5} \mathrm{~cm}^{2} \mathrm{~s}^{-1}$. which was about 3.5 folds larger than a previous reported value of $2.26 \times 10^{-5} \mathrm{~cm}^{2} \mathrm{~s}^{-1}$. 3 . The result indicated that the electrochemical reaction was quickly on the IL-CPE.

Analytical characteristics. Under the selected conditions the oxidation peak current was increased with $\mathrm{H}_{2} \mathrm{Q}$ concentration and the calibration curves were shown in Figure 6. The linear regression equations were got as $\operatorname{Ipa}(\mu \mathrm{A})=$ $-1.16 \mathrm{C}\left(\mu \mathrm{mol} \mathrm{L}{ }^{-1}\right)-25.07(\mathrm{n}=7 . \gamma=0.999)$ and $\mathrm{Ipa}(\mu \mathrm{A})=$ $-0.13 \mathrm{C}\left(\mu \mathrm{mol} \mathrm{L}{ }^{-1}\right)-185.45(\mathrm{n}=8 . \gamma=0.990)$ in the concentration range from $5.0 \times 10^{-6}$ to $1.0 \times 10^{-4} \mathrm{~mol} \mathrm{~L}^{-1}$ and $1.0 \times 10^{-4}$ to $5.0 \times 10^{-3} \mathrm{~mol} \mathrm{~L}-1$, respectively. The detection linit was estimated to be $2.5 \times 10^{-6} \mathrm{~mol} \mathrm{~L}-1$ (3\%).

The reproducibility of the determination was performed with 20 successive determinations of $5.0 \times 10^{-4} \mathrm{~mol} \mathrm{~L}^{-1}$ $\mathrm{H}_{2} \mathrm{Q}$. The relative standard deviation (RSD) was got as $2.9 \%$, which indicated the proposed method showed good reproducibility. The IL-CPE can be stored for about 3 weeks without a decrease of the response to $\mathrm{H}_{2} \mathrm{Q}$. which showed good stability. Table I showed the comparison results of ILCPE with other kinds of modified electrode for $\mathrm{H}_{2} \mathrm{Q}$ detection. From the table it can be seen that this method provided comparable linear range and detection limit by cyclic voltammetry with the advantages such as simple preparation procedure

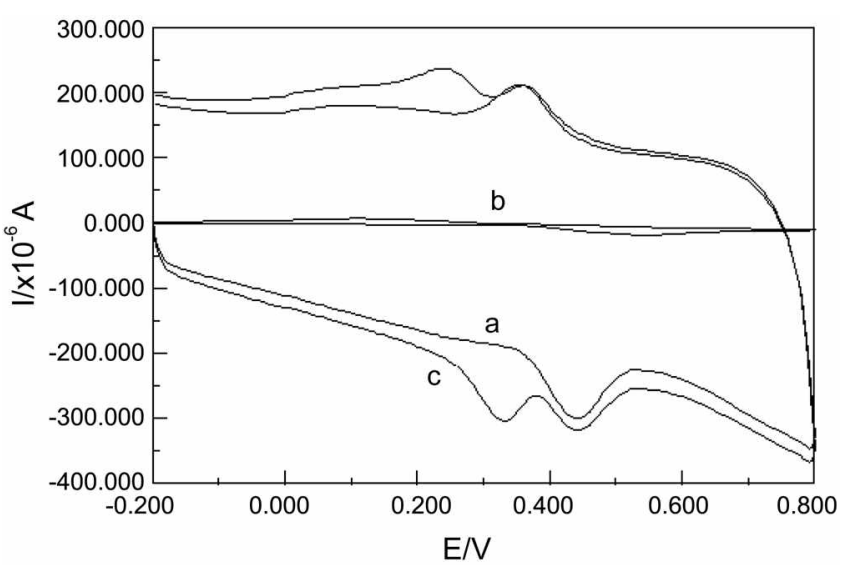

Figure 7. Cyclic voltammograms of $1.0 \times 10^{-4} \mathrm{~mol} \mathrm{~L}^{-1} \mathrm{CC}$ on $\mathrm{IL}-$ $\mathrm{CPE}$ (a) and a mixed solution of $1.0 \times 10^{-4} \mathrm{~mol} \mathrm{~L}^{-1} \mathrm{CC}$ and $1.0 \times$ $10^{-1} \mathrm{~mol} \mathrm{~L}-1 \mathrm{H}_{2} \mathrm{Q}$ in $\mathrm{pH} 2.5 \mathrm{PBS}$ on CPE (b) and IL-CPE (c). Scan rate: $100 \mathrm{mV} \mathrm{s}^{-1}$.

Simultaneously determination of $\mathrm{H}_{2} \mathrm{Q}$ and $\mathrm{CC} \cdot \mathrm{H}_{2} \mathrm{Q}$ and $\mathrm{CC}$ are phenolic compounds and ofen coexist as isomers in the envirommental samples. They have basic quinine

Table 2. Intluence of coesisting substances on the detemnination of $1.0 \times 10^{-1} \mathrm{~mol} \mathrm{~L}^{-1} \mathrm{H}_{2} \mathrm{Q}(\mathbf{n}=6)$

\begin{tabular}{ccc}
\hline Coexisting substance & Concentration & Relative enor (\%) \\
\hline Glucose & $20.0 \mathrm{mg} \mathrm{L}$ & -2.08 \\
L-Glutamic acid & $20.0 \mathrm{mg} \mathrm{L} \mathrm{L}^{-1}$ & -1.01 \\
L-Cysteine & $20.0 \mathrm{mg} \mathrm{L} \mathrm{L}^{-1}$ & -1.42 \\
$\mathrm{HSA}$ & $20.0 \mathrm{mg} \mathrm{L} \mathrm{I}^{-1}$ & -1.55 \\
DNA & $20.0 \mathrm{mg} \mathrm{L}$ & -2.31 \\
$\mathrm{RNA}$ & $20.0 \mathrm{mg} \mathrm{L}$ & -2.15 \\
$\mathrm{Na}^{-}$ & $2.0 \times 10^{-2} \mathrm{~mol} \mathrm{~L}^{-1}$ & -1.30 \\
$\mathrm{Zn}^{2+}$ & $2.0 \times 10^{-5} \mathrm{~mol} \mathrm{~L}^{-1}$ & -2.92 \\
$\mathrm{Ca}^{2+}$ & $2.0 \times 10^{-5} \mathrm{~mol} \mathrm{~L}^{-1}$ & -1.83 \\
$\mathrm{Cu}^{2-}$ & $2.0 \times 10^{-5} \mathrm{~mol} \mathrm{~L}^{-1}$ & -1.97 \\
$\mathrm{Mg}^{2+}$ & $2.0 \times 10^{-5} \mathrm{~mol} \mathrm{~L}^{-1}$ & -0.93 \\
$\mathrm{Br}^{-}$ & $2.0 \times 10^{-2} \mathrm{~mol} \mathrm{~L}^{-1}$ & -1.30
\end{tabular}

HSA: Human serum albumin, DNA: Deoxyribonucleic acid. RNA: Ribonucleic acid.

Table 1. Comparison of different modified electrodes for $\mathrm{H}_{2} \mathrm{Q}$ detemination

\begin{tabular}{|c|c|c|c|c|}
\hline \multirow{2}{*}{ Electrodes } & Linear range & Detection limit & \multirow{2}{*}{ Method } & \multirow{2}{*}{ Reterences } \\
\hline & $\left(17101 \mathrm{~L}^{-1}\right)$ & $\left(\mathrm{molL}^{-1}\right)$ & & \\
\hline MWCNT/GCE & $4.0 \times 10^{-5}-1.0 \times 10^{-4}$ & $1.2 \times 10^{-7}$ & DPV & 3 \\
\hline $\mathrm{ASP} / \mathrm{GCE}$ & $5.0 \times 10^{-6}-6.0 \times 10^{-5}$ & $9.0 \times 10^{-7}$ & DPV & 31 \\
\hline $\mathrm{P}-\mathrm{Glu} / \mathrm{GCE}$ & $5.0 \times 10^{-6}-8.0 \times 10^{-5}$ & $1.0 \times 10^{-6}$ & DPV & 32 \\
\hline MWCNT/GCE & $2.0 \times 10^{-6} \cdot 1.0 \times 10^{-4}$ & $6.0 \times 10^{-7}$ & LSV & 33 \\
\hline MWCNT/GCE & $6.0 \times 10^{-6} \cdot 1.0 \times 10^{-4}$ & $4.0 \times 10^{-5}$ & DPV & 34 \\
\hline $\mathrm{L}-\mathrm{CyS} / \mathrm{Au}$ & $2.0 \times 10^{-6} \cdot 2.0 \times 10^{-4}$ & $4.0 \times 10^{-7}$ & DPV & 35 \\
\hline $\mathrm{NG} / \mathrm{GCE}$ & $4.0 \times 10^{-6} \cdot 3.2 \times 10^{-3}$ & $1.02 \times 10^{-6}$ & $\mathrm{CV}$ & 36 \\
\hline GCE & $3.0 \times 10^{-5}-4.0 \times 10^{-3}$ & $2.0 \times 10^{-5}$ & $\mathrm{cV}$ & This paper \\
\hline IL-CPE & $5.0 \times 10^{-6}-5.0 \times 10^{-3}$ & $2.5 \times 10^{-6}$ & $\mathrm{CV}$ & This paper \\
\hline
\end{tabular}

MWCNT: Multiwall carbon nanotube. ASP: Aspartic acid. P-Glu: Poly (glutamic acid). L-Cys: L-Cysteine. NG: Nano-gold. DPV: Difterential pulse Foltammetry, LSV: Linear sweep voltammetry: CV: Cyclic voltammetry. 
Table 3. Detennination results of $\mathrm{H}_{2} \mathrm{Q}$ in synthetic wastewater samples $(\mathbf{n}=6)$

\begin{tabular}{|c|c|c|c|c|c|}
\hline Sample & Coexisting substances & $\begin{array}{c}\mathrm{H}_{2} \mathrm{Q} \text { added } \\
\left(10^{-5} \mathrm{~mol} \mathrm{~L} \mathrm{~L}^{-1}\right)\end{array}$ & $\begin{array}{l}\mathrm{H}_{2} \mathrm{Q} \text { found } \\
\left(10^{-5} \mathrm{~mol} \mathrm{~L}^{-1}\right)\end{array}$ & $\begin{array}{l}\text { RSD } \\
(\%)\end{array}$ & $\begin{array}{c}\text { Recovery } \\
(\%)\end{array}$ \\
\hline 1 & $\mathrm{H}_{2} \mathrm{Q}, \mathrm{AA}, \mathrm{Na}^{-}, \mathrm{Ca}^{2+}, \mathrm{Cu}^{2+}, \mathrm{Mg}^{2-}, \mathrm{Br}^{-}$ & 1.0 & 0.961 & 1.78 & 96.13 \\
\hline 2 & $\mathrm{H}_{2} \mathrm{Q}, \mathrm{AA}, \mathrm{Na}^{-}, \mathrm{Ca}^{2+}, \mathrm{Cu}^{2+}, \mathrm{Mg}^{2^{-}}, \mathrm{Br}^{-}$ & 3.0 & 2.934 & 4.51 & 97.80 \\
\hline 3 & $\mathrm{H}_{2} \mathrm{Q}, \mathrm{AA}, \mathrm{Na}^{-}, \mathrm{Ca}^{2+}, \mathrm{Cu}^{2+}, \mathrm{Mg}^{2-}, \mathrm{Br}^{-}$ & 5.0 & 4.887 & 2.25 & 97.73 \\
\hline 4 & $\mathrm{H}_{2} \mathrm{Q}, \mathrm{AA}, \mathrm{Na}^{-}, \mathrm{Ca}^{2+}, \mathrm{Cu}^{2+}, \mathrm{Mg}^{2-}, \mathrm{Br}^{-}$ & 7.0 & 6.790 & 2.60 & 97.00 \\
\hline
\end{tabular}

Conditions: $\mathrm{H}_{2} \mathrm{Q}, \mathrm{AA}\left(3.0 \quad 10^{-5} \mathrm{~mol} \mathrm{~L}{ }^{-1}\right), \mathrm{Na}^{-}, \mathrm{Ca}^{2+}, \mathrm{Cu}^{2+}, \mathrm{Mg}^{2-} \cdot \mathrm{Br}^{-}\left(6.0 \cdot 10^{-5} \mathrm{~mol} \mathrm{~L}^{-1}\right)$.

structure and can be electro-oxidated on the electrode. Sinultaneous determination of $\mathrm{H}_{2} \mathrm{Q}$ and $\mathrm{CC}$ level is of great necessary for their coexistance as isomers and highly toxic pollutants in envirolumental samples. So it is important to establish a precise method for the simultaneous determination of them without the previous separation procedure. Different kinds of modified electrode ${ }^{3.3(1.31}$ had been devised for the sumultaneous investigation of $\mathrm{H}_{2} \mathrm{Q}$ and $\mathrm{CC}$. In this paper IL-CPE also showed excellent ability to separate the electrochemical responses of $\mathrm{H}_{2} \mathrm{Q}$ and $\mathrm{CC}$. Figure 7 showed cyclic voltammogranıs of $\mathrm{H}_{2} \mathrm{Q}$ and $\mathrm{CC}$ in the mixed solution. It can be seen that on the IL-CPE CC exhibited a pair of redox peaks with Epa as $0.436 \mathrm{~V}$ and $\mathrm{Epc}$ as $0.356 \mathrm{~V}$ (curve a). While in the mixture solution of $\mathrm{CC}$ and $\mathrm{H}_{2} \mathrm{Q}$ only a pair of redox peaks could be observed (curve b) on the traditional $\mathrm{CPE}$ with $\mathrm{Epa}=0.540 \mathrm{~V}$ and $\mathrm{Epc}=0.116 \mathrm{~V}$. which indicated that the electrochemical responses of $\mathrm{CC}$ and $\mathrm{H}_{2} \mathrm{Q}$ were overlapped and could not be distinguished. By using ILCPE, the oxidation peak potentials were located at $0.328 \mathrm{~V}$ and $0.440 \mathrm{~V}(w . \mathrm{SCE}$ ) (curve $\mathrm{c}$ ), which were corresponded to that of $\mathrm{H}_{2} \mathrm{Q}$ and $\mathrm{CC}$. The separation of oxidation peak potential was got as $112 \mathrm{mV}$. So the IL-CPE showed excellent ability to separate the electrochenical response of $\mathrm{CC}$ and $\mathrm{H}_{2} \mathrm{Q}$.

Influences of coexisting substances. The influences of various coexisting substances including glucose. amino acids, metal ions. etc. on the determination of $1.0 \times 10^{-4} \mathrm{~mol} \mathrm{~L}^{-1}$ $\mathrm{H}_{2} \mathrm{Q}$ were further investigated and the results were listed in Table 2. It can be seen that few of them disturbed the determinations and the fabricated IL-CPE showed good selectivity

Sample analysis. The synthetic wastewater samples. which consisted of $\mathrm{H}_{2} \mathrm{Q}$, ascorbic acid (AA) and common ions including $\mathrm{Na}^{-}, \mathrm{Ca}^{2^{-}}, \mathrm{Cu}^{\hat{2}^{-}} . \mathrm{Mg}^{2^{-}} . \mathrm{Br}^{-}$, etc. were determined by the proposed method. The results were listed in Table 3 and it can be seen that the quantitative recovery in the range of $96.13 \%-97.80 \%$ was obtained. Therefore this proposed method was reliable practical and reproducible.

\section{Conclusions}

In this paper an ionic liquid $\mathrm{BPPF}_{6}$ modified carbon paste electrode (IL-CPE) was used as the working electrode for the investigation of the electrochemical behaviors of $\mathrm{H}_{2} \mathrm{Q}$. A great decrease of the overpotential and the increase of the peak current was observed on the IL-CPE. The electrocatalytic activity of IL-CPE was attributed to the higher ionic conductivity and inherent catalytic ability of ILs themselves, which resulted the fast electron transfer rate on IL-CPE. Under the optimal conditions. the oxidation peak current was in proportion to $\mathrm{H}_{2} \mathrm{Q}$ concentration in the range from $5.0 \times 10^{-6}$ to $5.0 \times 10^{-3} \mathrm{~mol} \mathrm{~L}^{-1}$ with the detection limit as $2.5 \times 10^{-6} \mathrm{~mol} \mathrm{~L}^{-1}(3 \sigma)$. The IL-CPE showed good ability to separate the electrochemical responses of $\mathrm{H}_{2} \mathrm{Q}$ and $\mathrm{CC}$ in the mixed solution. The presence of coexisting substances showed no interferences to the determination and the established method was successfully applied to the $\mathrm{H}_{2} \mathrm{Q}$ detection in synthetic wastewater samples.

Acknowledgements. We are grateful to the financial support of the National Natural Science Foundation of China (No.20405008. 20635020) and the Open Foundation of State Key Laboratory of Chemo/Biosensing and Chemometrics of Hunan University (200615).

\section{References}

1. Duvall. S. H.: McCreery. R. L. Anal. Chem. 1999. 71.4594

2. Murray. R. W. Acc. Chent Res 1980. 13. 135.

3. Qi. H. L.: Zhang. C. X. Electroanalvsis 2005. 17.832

4. Buzzo. M. C: Hardace C. Compton, R. G. And. Chem. 2004, 76. 4583 .

5. Li. Z.: Liu. H.: Liu. Y; He, P; Li, H.; Li, J. H. Langmai $2004,20$. 10260 .

6. He. P.: Liu. H.: Li. Z.: Li. J. H. J. Electrochem. Soc. 2005.152. El46.

7. Maleki, N.: Safavi. A.; Tajabadi. F. Anal Chem. 2006, 78. 3820.

8. Zhao, F.: Wu, X: Wang, M.; Liu, Y.: Gao, L: Dong. S. J. Anal. Chem. 2004, 76, 4960 .

9. Sun1. W.: Wang. D. D.: Gao. R. F.: Tiao. K. Electrochem. Contmut. 2007. 9. 1159

10. Surn. W: Yang. M. X.: Jiao. K. Anal. Biomal, Chent 2007. 389. 1283 .

11. Yan. Q. P: Zhao, F. Q.: Li, G. Z; Zeng, B. Z. Electroanalysis 2006. 18,1075

12. Li. J. W.: Zhao. F. Q.: Xiao. P.: Zeng. B. Z. Chinese J. Anol. Chent 2006. 34.S5.

13. Li. C. M.: Zan1g. J. M.: Zhan1. D. P.: Chen. W.: Sut1. C. Q.: Teo. A L.; Chua. Y. T:; Lee, V. S.: Moochhala, S. M. Electroandysis 2006. 18,713

14. Zhao. Y. F.; Gao. Y. Q; Zhan. D. P.; Liu. H: Zhao. Q; Kou. Y; Shao. Y. H.: Li. M. X.: Zhuang. Q. K.: Zhu. Z. W. Talamta 2005. 66.51

15. Lee. B. L.: Ong. H. Y: Shi. C. Y: Ong. C. N. J. Chronatogr. 1993. 619,259

16. Sakodinskaya, I. K: Desiderio, C.: Nardi, A.; Fanali. S. J. Chromatogr 1992. 596,95 .

17. Firth. T.: Rix. I. Anatust 1986. 1H. 129

18. Wang. L. H. Anahyt 1995. 120.2241. 
19. Aihara. M.: Fukata. M. Anat. Lett. 1987. 20.669.

20. Vieira. I. C.: Fatilello-Filho. O.: Angnes. L. And. Chint Acta 1999. 398.145 .

21. Vieira. I. C.: Fatibello-Filho, O. Talanta 2000, $52,681$.

22. Oliveira. I. R. W. Z: Vieira. I. C : Lupetti. K. O. Fátibello-Filho, O.: Fávere. V. T.: Laranjeira. M. C. M. Anal. Lett. 2004 15, 3111 .

23. Maleki. N.: Safavi. A.: Sedaghati. F.: Tajabadi. F. Anal. Biochem. 2007.369. 149

24. Musameh, M. Wang I Ahal Chim Atca 2008, 606, 45.

25. Sum, W: Yang, M. X.: Gao, R. F: Jiao, K. Electroanalysis 2007. 19,1597

26. Nicholson. R. S.: Irving. S. Anat. Chem. 1964. 36. 706.

27. Zhang. Y.: Zheng. J. B. Electrochim. Acta 2007. 52.7210.
28. Nicholson. R. S. dinal. Chem. 1965. 37. 1351.

29. Ansont. F. C. Anat Chem. 1964. 36.932.

30. Peng. J.: Gao. Z. N. Anal. Bioanal. Chem. 2006. 384.1525.

31. Wang, L: Huang. P. F.: Wang, H. J; Bai, J. Y.; Zhang. L. Y.: Zhao. Y. Q. Anal. Chim 2007, 97, 395.

32. Wang, L.; Huang. P. F.: Bai, J. Y.: Wang. H. J : Zhang. L. Y.: Zhao. Y. Q. In. J. Electrochem. Sci, 2007.2. 123.

33. Ding. Y. P.: Liu. W. L.: Wu. Q. S.: Wang. X. G. J. Electrounal. Chent 2005, 575, 275 .

34. Liu, X. X; Wang, L. S; Zhang. S. F.: Deng, X. R:; Tang, X. L.; Sun. D. C. Chinese J. Instrumental Anal 2007, 26, 24.

35. Wang, S. F.: Du. D. Sensors 2002. 2. 41.

36. Zhang. Y: Yuan. R.: Chai. Y. Q.: Zhuo. Y.: Fu. Y. Z. J. Southwest China Nomal Liner: 2006. 31. 86. 